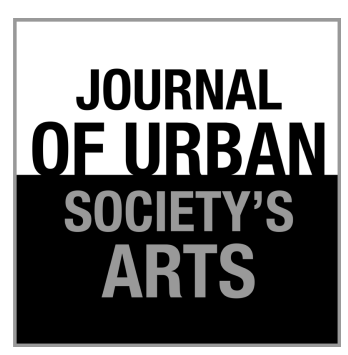

Volume 2 Nomor 1 , April 2015: 25-34

\title{
Strange Encounter: Depicting An “Other” Reality for Young Readers
}

\section{YOU Chengcheng}

Department of English Literature, University of Macau

E-mail: YB27301@umac.mo

\begin{abstract}
This article explores fantastic encounters between humans and non-humans in Chinese and Japanese Children's literature. Naoko Awa's collection of short stories The Fox's Window and Other Stories is closely read to elucidate narrative features of what I call as "strange encounter", the magic realistic human-animal encounter in Chinese and Japanese cultural context. Chinese supernatural literature and cultural tradition of yaoguai, which have been assimilated into Japanese culture (Japanese yōkai), are referred to throughout my discussion. Todorov's approach to the fantastic, Judith Zeitlin's study of Strange Tales of Liaozhai Studio, and Rosemary Jackson's study of fantasy are drawn upon to illuminate the meaning of encounters between men and animals. I argue that magic realism as a relatively new genre for young readers, not only reflects the author's individual creative experience of the fantastic but also partakes in the sense of an "other" reality that resonates throughout a cultural community.
\end{abstract}

Keywords: encounter, reality

\begin{abstract}
ABSTRAK
Perjumpaan Ganjil: Gambaran suatu Realitas "Liyan" bagi Pembaca Muda. Artikel ini membahas perjumpaan fantastis antara 'manusia' dan 'non-manusia' di dalam sastra anak Cina dan Jepang. Antologi cerita pendek karangan Naoko Awa The Fox's Window and Other Stories akan dikupas untuk memaparkan fitur naratifyang disebut sebagai 'perjumpaan aneh' (strange encounter), perjumpaan magis-realis antara manusia dengan binatang dalam konteks kebudayaan Cina dan Jepang. Karya sastra supernatural Cina dan keberadaan yaoguai yang telah diasimilasi dalam kebudayaan Jepang (disebut youkai) menjadi sebuah referensi penting dalam artikel ini. Pendekatan fantasi dari Todorov, studi Judith Zeitlin tentang Strange Tales of Liaozhai Studio, dan studi fantasi dari Rosemary Jackson digunakan untuk memperjelas arti dari perjumpaan antara manusia dan binatang. Magis-realis sebagai sesuatu yang baru bagi pembaca muda tidak hanya merefleksikan pengalaman kreatif pribadi sang pengarang akan fantasi, tetapi juga berperan dalam pembentukan realitas "liyan" dalam sebuah komunitas budaya.
\end{abstract}

Kata kunci: perjumpaan, realitas

\section{Introduction}

There has been a long literary tradition of depicting fantastic encounter between a child and a non-human talking creature in children's literature.
A child walks into the wood, when lost, encounters a talking animal or fairy. Many variations are developed from this motif, for instance, Alice's encountering a talking fawn in a wood where things have no name in Lewis Carroll's Through the Looking 
Glass. Alice then rambles with her dear fellow friend in the wood where hierarchical relationships cease and interspecies dialogues are possible. Dot and the Kangaroo is another example. A five-year-old girl Dot is lost in the Australian outback. When befriended by a talking kangaroo, she is able to find her way back. Conventionally, magic or supernatural element becomes an integral part of these literary encounters, from which a number of strange figures appear. Ghosts, goblins, dreams, metamorphosis, talking animals and the like lurk and blend into the character's fictional world with an overt didactic or entertaining purpose. Yet, these encounters are bound up with an unsettling assumption that there is little realism but magic in these literary practices, because they take place in another plane of reality which is different from ours.

Since magic realism has reached the realm of children's literature in the twentieth century, authors of children's fictions have explored ways to transgress boundary between fantasy and reality to a different pitch of sophistication. David Almond's Skellig (1998), Neil Gaiman's The Graveyard Book (2008), and Patrick Ness's A Monster Calls (2011) can each, in its way, be considered a magic realist work. Characterized by the placement of magic in the realistic or mundane world, they entail the breakdown of the unity of time, space and character, and of the distinctions between human and non-humans; each also suggests a delight in these subversions. Moreover, the psychological underpinnings are unveiled to tell us what fears or desires run underneath the magic realistic experiences.

While much critical attention has been given to western children's stories that feature encounters between humans and non-humans, my study aims to scrutinize the magic realist writing about man-animal encounters in a different cultural community. Located in the cross-cultural context of imaginary beings, this study examines Chinese aesthetics of the strange and then looks in detail at Chinese and Japanese works, ranging from PuSongling's Liaozhaizhiyi (Strange Tales of Liaozhai Studioapproximately 1766) to Naoko Awa's The Fox's Window and other Stories (2010). From textual analyses, I would like to explore how boundaries between humans and non-human animals, subjects and objects have been transgressed in the Chinese and Japanese strange tales, and to what extent they have influenced modern sensibilities in depicting the magical reality for young readers.

\section{Cultural Background of Imaginary Beings}

The dynamism inherent in magic realistic writing is included in the creation of fabulous animals and liminal humans. Animals in arbitrary combinations or grotesque human bodies have their early origins in ancient countries such as Greek and China. Horace's opening in ArsPoetica presents a picture of chimera with a human head, horse neck, bird feathers, the face of a pretty girl, and the tail of black fish in a single image. It reflects the classical aesthetics of merging the odd and unexpected into the unity and harmony. To couple with this opening, we can find imaginary beings readily available in Greek mythologies or eastern bestiaries, for instance, sphinx, mermaid, al-buraq, griffin, minotaur. In his book Imaginary Animals: The Monstrous, the Wondrous and the Human, Sax notes that what we call "imaginary" "might have a very palpable reality, but in a cultural environment which is very different from our own" (43). This claim is reminiscent of Michel Foucault's observation in terms of cultural differences that breed these imaginary beings. It starts with his reading of Luis Borges' article "The Analytical Language of John Wilkins", in which Borges cites a passage of the animal classification from "a certain Chinese encyclopedia": "Those Belonging to the Emperor; Embalmed; Tame; Suckling Pigs; Sirens; Fabulous... That From a Long Way Off Look Like Flies"(Foucault, xv). There are doubts about whether this animal classification actually stems from any Chinese encyclopedia or is just a fictional make-up. While most people would find this classification of animals ludicrous, Foucault takes it an opportunity to recognize the limitations of one culturally-defined thinking mode:

"In the wonderment of this taxonomy, the thing we apprehend in one great leap, the thing that, by means of the fable, is demonstrated 
as the exotic charm of another system of thought, is the limitations of our own, the stark impossibility of thinking that (xv-xx)".

An individual cognitive limitation is, by all means, prescribed by its fundamental codes of a culture ranging from what governs its language, its schemas of perception to the order of things. Foucault and Sax's insight provides a loophole from which we see the importance of evaluating orders of things in a given cultural context. Only without bestowing names or imposing anthropocentric values on these imaginary animals can we construe their psychological, spiritual, and social revelations.

In the theoretical view, imaginary animals are often regarded as a sort of "second self" or "monstrous double" of an individual being or even an entire human race, or alternatively, "others" harnessed with the anthropocentric bias. For western readers, they exist as aliens, ghosts, werewolves, zombies, or anthropomorphized animals. In China and Japan, these semi-animal, semi-human, and hybrid figures and otherworldly creatures are commonly known as Chinese yaoguai and Japanese Yōkai. Rooted in the folklore, they enact an animalistic instinct that ancient people intimately feel towards the nature and death. In the Chinese cultural context, a typical bestiary assembles all possible imaginary beings, including yaoguai (demons, ghosts, monsters, and spirits), divine figures (semi-gods, gods, heroes), celestial phenomena (winds, rains, rainbows, stars), geographical formations (mountains, minerals, rivers, seas) as well as unusual flora. It is best exemplified in Shanhaijing (Guideways through Mountains and Seas, the 4th century BC), a mythical geography and fantastic ethnography, full of wondrous stories and creatures. It contains a treasury of information about the ancient Chinese worldview, from which we can see a Chinese bestiary of imaginary creatures is respected and recorded. To cite a few, the first goddess of Chinese mythology nüwa, nine-tail fox, jingweian indomitable bird, are among a number of hybrid animals and hybrid human animals.

It is a characteristic of Chinese traditional worldview that these creatures and natural phenomena are regarded as a constituent part of one's conceptual cosmos. But the existence of these imaginary animals does not merely reflect animistic or demonological beliefs in the supernatural world in ancient China. Among three philosophical schools that affect Chinese sensibilities, Buddhists see no strict delineation between humans and non-human animals whereas Taoists develop a harmonious ethical discourse of achieving balances in all living beings. The practice of Buddhism and Taoism gives rise to a great abundance of yaoguai (Bai 2013), which recur in Chinese legends, folklore, and supernatural fiction. During late Qing dynasty, these yaoguai are particularly written to break free from social restraints and invert the Confucian orthodox of five dominant relationships (king-subject, father-son, husbandwife, elder brother-younger brother, and friendfriend). PuSongling's Liaozhai best epitomizes the Chinese supernatural and/or conceptual paradigm regarding yaoguai, in some ways at least, instills a "transformative, regenerative energy" to the then fettered Confucian system (Dodd, 2011). Most prominently, it is characterized by a credulous but complicated combination of fancy and reality, animals imaginary and real. Five hundred and twenty strange tales recorded in Liaozhai dramatize a world of foxes, snakes, ghosts, and spirits transformed into humans for various secular motives. They unmistakably demonstrate that the self and other, subject and object have been inseparably interrelated and intrinsic to the traditional Chinese perception, which become the ground of Chinese aesthetics of the strange.

\section{Chinese Aesthetics of Strange}

Tzvetan Todorov once defined the hesitation experienced by a reader in confronting an apparently supernatural event as an essential hallmark of the western fantastic experience (1973:25). In contrast to Todorovian principle of reader's hesitation, Judith Zeitlin in her study of Liaozhai illustrates different features of the fantastic embodied in the Chinese concept of "strange". Etymologically, it is associated with $y i$ (different), guai (anomalous) and $q i$ (marvelous). Zeitlin points out that the strange in Liaozhai "often results when things are paradoxically affirmed and denied at the same time. 
In other words, the boundary between the strange and the normal is never fixed but is constantly altered, blurred, erased, multiplied, or redefined" $(1993,7)$. This observation implies that the reader's hesitation is less generated in the Chinese strange tales. Western supernatural stories problematize well-cut boundaries between the self and other, the subject and object, the life and death, the reality and illusion. Comparatively, Chinese strange tales that entail liminal characters actually generate the shifting, erasure or proliferation of boundaries. In other words, boundaries are not static and normalized constructs, but flexible and changeable.

Fundamental to these transcendental destabilizations is the creation of a Chinese characteristic dream world. It cannot be divorced from both the external cosmological correspondence and the interior motivation. As Zhuangzi does in his dream, he could not tell whether it was Zhuangzi who had dreamt the butterfly or the butterfly dreaming Zhuangzi. Zeitlin reads Menglang "A Dream of Wolves" and Hu meng "A Fox Dream" to illustrate the motif of dream in Liaozhai. The former chronicles an old man's dream about brutal tigers and wolves, which later attests to what becomes the fate of his two sons. The latter is PuSongling's recount of his friend who finds him getting involved with many fox spirits in dream-like but actual states. These two stories either focus on the allegorical or fictional nature of the dream to form an "illusory spectacle" (171), a major trait of Chinese fantastic actualization in the dream world. In both cases, life, dream, and drama are interrelated, serving as the "triple analogy" of this strange spectacle (171). All in all, a Chinese strange dream world link the dialects of dreaming and wakeful states with the poetics of illusion.

A lack of strict demarcation between the subject and the object, the animate and inanimate is inherent in the Chinese tradition of strange tales. Everything is bound up with the element of qing (emotion, desire, sentiment) in its infinite process of transformation and reincarnation. That is how they evolve or regress to the status of yaoguai. In Liaozhai, a famous story "The Ethereal Rock" (Shi Qingxu) narrates about a scholar who is obsessed with a rock and even willing to sacrifice his life for it. The rock grows sentimental and attached to its owner. In the end, the tale culminates in the rock's self-sacrifice to be buried with its owner against all odds. The rock, with its feelings acquired, becomes sentient and quasi-anthropomorphic. It is no longer an object of desire, but a subjective agent. This is an important ingredient of Chinese aesthetics of the strange: physical or sentimental metamorphoses from the object to the subject.

Furthermore, no explicit distinctions are made between the lived reality and the dead. The ghost sensibility is imbedded in the magic realistic otherworld of Liaozhai. Boundary-stridden figures move across the realm of the dead to the land of living easily, interfering with human affairs. One of the most remarkable tales in Liaozhai "Painted Skin" depicts a ghost who paints her disfigured face daily to seduce a young scholar. When the ghost exposes her original grotesque image, the scholar is horrified to death. With his wife's undaunted help, however, he is able to gain his heart back and come alive again. Different from the western concept of metamorphosis that suggests more or less the physical trapping in an animal body, artistic representation of the transformative body in Chinese strange tales implies greater possibilities for dynamic change, furnished with a belief in the materiality of ghosts. Iwasaka and Toelken argue that the lack of demarcation between the land of the living and that of the dead is also central to Japanese folklore and that the "fields of illusion and reality overlap and interact, and may indeed not be distinguishable", resulting in "a kind of ambiguity and simultaneity which can thrive on anxiety and guilt" (Balmain, 2008:68). Essentially in strange tales, ambiguity reigns to heighten the sensation of the strange. It generates a carnivalesque effect, when the dead can cross boundaries to communicate with the living and vice versa. In this liminal borderland, human desires and anxieties assume spectral qualities, enchanted and then disenchanted.

Quite a number of modern Chinese and Japanese literary works are marked with a semiotic operation of the strange: metamorphoses, ghostlike appearance, illusory dream world and confusing boundaries. Take the first Chinese Nobel laureate Mo Yan for example. His fiction Life and Death 
are Wearing Me Out merges Chinese folklores, history and magical resources into sequential animal reincarnations of a man called Ximen Nao. Animal narrative voices of a donkey, an ox, a pig, a dog, a monkey (Ximen's reincarnations) are tinged with emotions and memories of their previous existence. This writing style shares many commonalities with magic realism as a genre. They both entail a problematic relationship to the real, a real that the function of writing the western literary discourse attempts to achieve in mirroring or subvert the empirical reality. In the western magic realist stories, the binary oppositions (of the dream and waking reality, the living and dead, the subject and object) are foregrounded as opposing creative forces. However, magic realist tales in China and Japan, contextualized in the literary discourse of qing and dreamworld, defy all dualistic demarcations. However weird or abnormal a creature or phenomenon is, it credibly coexists with the materialistic everyday life. Given this cultural context, human-nonhuman encounters can be said to work as a touchstone to reveal an "other" reality that resonates throughout the Chinese and Japanese society. Such reality, purported by the presence of various kindred spirits, has been echoed down in the literary works for young readers.

\section{Strange Encounter}

Peng Yi, a Chinese children's writer, is enchanted with the theme of yaoguai in his fantasy. His fictional world is full of transformed beetle, white fox, phantom hero and other strange creatures. His recent picture book Yaoguai Mountain (2015) subtly touches on the subject matter of yaoguai. This story is about four children setting their foot in amountain full of crevices, in which a variety of demonic figures dwell. While they were playing a game of "yaoguai seek, children hide", a hidden monster trapped a girl. Other three children ran away from this mountain in a panic. A year later, they received a letter from the lost girl who entreated them to finish the game in that mountain. Otherwise she would remain as one of the yaoguai there. When those children finally boosted their courage to be friend a full mountain of yaoguai, the lost girl was saved and returned to the human shape. The author wrote that, "There is a yaoguai mountain in every child's heart. It is up to you whether you want to get around it or meet it head on" (2015:1). yaoguaiis here a symbol of imperfection and darkness that lurks around life's corner. Throughthe children's encounter with yaoguaiin a magic realistspace, they learn how to smooth theirinterior discrepancies, recovering the norm through their courage and friendship. This story portrays an interesting literary scene that prompts our thinking: what affect does this strange encounter serve in a magic realist story for the children? Consonant with Chinese aesthetics of the strange as mentioned above, a close analysis of Japanese fantasist Naoko Awa's works can further cast light on this topic.

Naoko Awa is a prominent children's writer, well-acclaimed for infusing love and warmth into her fantastic writing. It is said that reading Naoko Awa reminds of both Beatrix Potter and Yanagita Kunio (the father of Japanese native folkloristics), mostly because she merges folk religion and environmental ethics into her stylized works about animals and yaoguai. Her stories are usually categorized as modern fairy tales. Yet whether her works are fairy tales should be treated with skepticism. I would say that she adeptly draws on various elements from different generic conventions and blend into her own magic realistic style, as her stories entertain no doubts about the magic in the real.

The Fox's Window and Other Stories, translated and published in 2000, is her first collection of fantastic stories translated in English. Characteristically in Naoko Awa's stories, the protagonist strides over two worlds, of illusion and reality. There is not a marked borderline between things or worlds, as she remarks:

"I like the boundless feelings brought by a fantastic self in a fantastic world... I write fantasy because I love the rainbow color that shifts elusively over the borderline between the fantasy and the reality... that borderline has enchanted me a lot since my childhood" (Peng, 2005:64).

Therefore, the atmosphere she enwraps her characters and plot is hallucinatory. "The Bird and 
the Rose" and "A Summer's Dream", for instance, blur borderlines of the perceptibly real, with a hint of the fantastic and dreamy. "The Bird and the Rose" starts with a shuttlecock game between a big sturdy girl and a small weak girl. Falling short of the strength, the small girl misses the shuttlecock all the time. Blamed by her friend, she chases a shuttlecock to the other side of the hedge that connects with a mysterious garden. In the garden, the shuttlecock turns into a bird, subsequently shot down by a boy. He invites the girl to eat the bird pie (with rose petals) made by his mother back at home. Unwittingly the boy's mother casts a spell on her. If she falls asleep, she will immediately be morphed into a rose. The boy, however, chants another spell and helps the girl escape:

"She jumped over the brook and passed under the large ginkgo tree. She kept slipping on the velvety moss, almost falling. Every time she almost lost her footing, she felt the woman's spell grow stronger. She felt turning into a rosebush. Her body began to feel stiff, but her hair smelled nice... She kept running even though her legs felt like rose stems" (173).

This scene seems to revisit the moment when Daphne escapes Apollo and turns into the laurel tree. But before further horror or disbelief seizes her, the girl returns to the reality with a meaningful smile. She feels pretty as a rose and happy as bird. The dream, real or not, empowers and enlightens hereto find back her own confidence.

"A Summer's Dream" depicts another similar scene. An old man inserts his fingers into his ear and pulls out a cicada. Instead of being horrified by this scene, a young man who runs a corn stand is amazed at the beauty of this cicada. Handing the cicada to this frustrated young man, the old man asks him to "ride the sound" (130). The cicada's droning transports the man into a seemingly real dreamscape. He is woken up by a young girl Kana who speaks to him in a soothing voice, despite her deafness in the reality. Soon the man knows that Kana is holding a wedding under a well-lighted tree. The tree is hung over with candies. Whoever eats the candy is endowed with the ability to speak, including cicadas. The young man runs down a beautiful passageway hand in hand with Kana, in the hope of catching up with the wedding. At the end of the passageway, there is a door that sends the young man back to the reality again. The cicada in his ear flies back to the old man's ear. At that moment, he witnesses the metamorphosis of the old man:

"As the setting sun flickered on the old man's face, he gradually turned into a tree - an old beech standing tall in the forest. The cicada was perched on its branch, motionless... The tree lived for almost an eternity" (139).

These two tales can be categorized as "portalquest fantasy" in Farah Mendelsohn's words. There is a portal that connects the worlds of the real and magical, through which, the protagonist steps out his usual world and enters a fantastic place. Intriguingly, the portal is always linked with a dream as a transitional zone, through which the characters negotiate with frustrations and imperfections in their life. The tree, roses, and the bird are magical messengers from nature to bring a dire human scene alive. Although the magic loses its validity in the real life, this threshold renders the story with a strange but heart-warming air: the deaf is to be heard, the vulnerable is to thrive beautifully, in other stories, the living is to communicate with the dead or spirits ("A Tale of White Mufflers"), the blind is to experience sky's color ("The Sky-colored Chair"). Awa then builds a narrative of restoration in a problematic childhood that is vulnerable to diseases and inequalities. Here the alterity is found in the possible discrimination against those who are poor, weak, disabled, and dying. A synaesthetic and utopian quality is underscored by each boundarycrossing dream, assisted by a magical but ordinary device or character. Taking this idea further, these stories are grounded in poses of innocence and simplicity, enabling young readers to form their own empathetic understanding of "others" in an outlandish realm.

Another recurrent element that constructs Awa's tales is transformation. Japanese folktales are populated with creatures with the ability to transform, such as foxes, tanuki (raccoon dogs), cranes and even mountain witches. They frequent Naoko Awa's dream world. Not limited to animals, every life being is capable of its transformation to 
embark on a journey of self-actualization and selfdiscovery. Every nonhuman creature can readily interact with human beings and create a mixture of mystery and anxiety. This becomes the element of suspense that drives the plot forward. There are two functions of deploying the transformation as narrative means. For one thing, the kinship between the child and animal is pronounced. Animals can sometimes be read as children in disguise. The creation of every talking animal encapsulates Awa's earnest love for children and animals, even when they are transmuted into intimidating monstrosities. This may account for the mutability between the human and animal without producing an uncanny atmosphere. For another, Awa's deployment of the metamorphosis also heightens the spectators' sensation in participating in a carnival where the lower-class stratum is empowered to transform its status and where an intrinsic interconnectedness in all creatures is nurtured. As Tess Cosslett notes that child "exists in a space of play in which boundaries could potentially be transgressed" (2002:476), plots of transformations cater to the children's fantasy of a changeable physical world, connecting them with boundaries of space, time and existence. In this way, the vitality and freedom of playful subversion ripple outward.

Besides the use of transformation, and dream spectacle, another appeal of Naoko Awa's depicted encounter lies in the emergence of a wide spectrum of sentient creatures, mostly talking animals. Humans, animals, plants, supernatural creatures move across different worlds easily in a matter-offact way. "The Night of Pickled Raddish" depicts a story about the character Mohei's encounter with a wild boar in the wood and later he is invited to join the boar's night of picnic. In "The Forest of White Parrots", a little girl walks into another worldly forest after a parrot from an Indian's jewel shop. In "The Hat with Wild Rose Rim”, a young mistress, when lost in the mountain, comes across a doe and a fawn who wears a hat with wild rose $\mathrm{rim}$. She is invited later to inculcate the latter with lessons of manner. What structures Awa's stories is consistently familiar. It starts with a character getting lost in the wood, then a phantomlike animal emerges and looms large in the sight. Senses of wonder and horror are least expected when the animal starts talking. Any man-animal encounter is met without a grain of doubt or fear. No one will be shocked or panicked if a weasel shows up on a roller skate. When a young man tells his wife that he is invited to participate in the boar's picnic, for example, his wife replies: how admirable is that! In this respect, talking animals and humans are mixed and communicate harmoniously without even a slight gothic note.

"The Fox's Window" is the most well-known one. It is a first-person narrative. The protagonist may be a young hunter, because when he was lost in the woods, he still had a rifle on him. He was gradually put off guard when he was immersed in the beauty of "an open field of bellflowers stretching as far as the eye could see" (41). Then a fox cub emerged to catch his attention. The man chased him till he arrived in a bellflower dye shop. The fox in human shape greeted the man and offered to dye his fingers blue. The man doubted this idea with a disdainful smile. Rather than giving up, the fox drew a diamond-shape window on his own fingers. The man peeked through the window and surprisingly saw a beautiful white mother fox there. The fox explained lightly that her mother was shot to death and only in this way could she be conjured alive. When the hunter asked for a dyed window on his fingers, his lover immediately leapt to his sight through the window. Deeply touched, he offered to pay the fox with anything he wanted. The fox withdrew his rifle and then showed the man the way back. All the way from the woods to the man's cottage, he was enthusiastic at this magic. He made a window again through which his mother and their past pastoral dwelling were seen. Ironically the man washed his hands as soon as he arrived at home. Before he knew it, the magic was gone. The story ends with a sentimental change in the protagonist. He was sensitive to the fox's cry while making every effort to dye his fingers with windows.

In Japanese cultural tradition, foxes are known as transgressive animals. Their malleability allows them to be uncanny and subversive. In Naoko Awa's stories, however, shape-shifted foxes are depicted as goodwill messengers. A critique of 
human cruelty and environmental destruction is explicit in this story. The open field of bellflowers may be a dream reality that no longer exists while the hunter with a gun is routinely associated with the human violence that spoils the natural scene. Artistic affect arises while dialogues between the hunter and the fox are possible. The hunter is put to the same situation with the dyed window on his fingers. His rapture at the sight of the girl he loves is no greater than the fox's pain at the glimpse of his deceased mother. Dyed blue window is an enchanting image that connects the living and the dead, the human and the animal to the same effect. Empathy plays a central role in this narrative when it also involves the topic of death. Aside from an ostensible sentiment about the nature and animals, Awa's stories are also characterized with a sense of isolation and sorrow. But hope and love is often intertwined with mortality, vulnerability, and solitude, as shown in "The Fox's Window" and "Forest of the White Parrots". "A Summer's Dream” exposes a young man's pining "to live in her (Kana's) world-a soundless place, a sadly bright place where only lights and colors existed" (134). "Forest of Voices" shows a dark forest full of thick old oaks known as "mimic trees", in which, "countless animals had lost their way ... Like someone scared of his own reflection in the mirror, every animal going stray among the trees was surprised by its own echo and ran in circles until it collapsed and died" (87). It is striking that themes of loss and melancholy govern almost all Awa's stories. To me, it not only manifests her individual emotional style, but also reflects Naoko Awa's cultural memory of the strange in Japanese folklore. In an interview, she admits that"I am obsessed with the word yaojing (goblin, spirits), and find it very fascinating... but this word has been stereotyped, sadly, its dynamic grace is lost” (Awa, 1977). Therefore, Naoko Awa never uses this term directly, instead, she creates charming images of tree spirits, wind spirit ("Becoming the Wind"), and flower fairy ("Flower Town") in fresh ways and reanimate these characters with poetic qualities.

Awa's stories, deeply involved with nature, honor dreams of a summer sunflower, autumn susuki field and evening sea. The seasonal references or spirits can hardly escape the reader's attention. They pulsate with passionate human gaze. Together with talking animals, these sentient creatures are full of emotions (melancholy, warmth and sympathy), leading the protagonist into a strangely sad but beautiful and colorful world. Similar to haiku, an old Japanese form of poem, every Awa's story conjures up whole complexes of natural images and associated feelings. These sentiments for the nature and animals are, in fact, consonant with the literary discourse of qing and an aesthetic principle in Japanese psyche-mono no aware (lit. the pathos of all things). Firstly, talking animals under her pen take on a powerful emblematic quality of qing. The menacing mimetic trees in the forest of voices are lulled to sanity and peace with the maternal love, symbolized by the song the lost girl sings. Animals that die of hunting, such as rabbits in " $A$ Tale of White Mufflers" and cranes in "The House of Cranes", become a haunting and then forgiving force that pacifies all tragic loss. Almost without exceptions, these animal characters are imbued with intense love for not only their own species but also human beings. It is the empathy of understanding how a lonely character would feel oneself if one found oneself in the same circumstances as the other. The circumstance of the hunter and the fox illustrates this point. Secondly, her stories espouse the ideas of cherishing transient beauty of all things. According to Jerome Shapiro, mono no aware is both an appreciation of the ephemeral nature of existence, or the "impermanence of things", and "a profound sense of sympathy that is more difficult to define" (2002; 2004), leaving a feeling of nothingness and melancholy. Therefore, no matter how eager the young hunter wants to retain the dyed window on his fingers, he is unable to reclaim such enchanting memory. An author experiences his fictional world of talking animals with great joy. However, as soon as he leaves, he forgets to ask for the passcode to the inn. The tanuki disguised as human children bring the warmth and love to an aged couple. But this magic realistic reunion cannot last long. The alternative world ruptures the order of their mundane reality and reorients their perspective on living with inextinguishable hope. Typically it ends with a cheerful sigh when 
dream visions/encounters are vanishing.

In contrast with the western human-animal encounter that mainly rests on binary oppositions, the strange encounter in these eastern texts manifest fluid and ambiguous qualities of an "other" reality. In her analysis of Japanese anime Inuyasha, Mio Bryce notes that Japanese society is "highly contextual and empathy-oriented and which embraces ambivalence and fleetingness within a homogenous yet hierarchical structure" (Bryce, 2012:163). Reporting the perception of the ambiguous and precarious situations, with the aforementioned idiosyncrasies of boundary confusion and empathy as an essential quality, is distinctly Japanese and Chinese ways of depicting a strange reality. The transient nature of all life and the confusion between the real and unreal resound long through Awa's stories, which reveal possible space for understanding life beyond hierarchical categories. It is the fictional space of affectionate yaoguai. Once long exposed to the sentiments, even a flower can be transformed into a spirit; yearning for freedom makes a human mother drift away as a wind; wings can grow from a heart that dreams of flying. If this place is named, it is what Naoko Awa calls as "Red Rose Inn". In her novella Guests of Red Rose Inn, the author, when walking astray, comes across her protagonist in a wood. The protagonist runs an inn that inhabits all kinds of talking animals that endear him: the cooker fox, bird helpers, Mrs. Rabbit the housekeeper, the wind spirit and her fiancée a deer as guests. There are imaginary and delightful happenings in this animal world every day. Retreating into this enchanting oriental forest when men lose their ways, we find animals a profound revelation about who we are and where we should head for. Finally it is the talking animals that become the source of therapeutic power and help the human hero negotiate his way out of personal predicaments.

Generally speaking, Naoko Awa's stories employ many elements of traditional strange tales: a weird but matter-of-fact encounter in a dreamscape, careful nuancing of sensibilities, subtle borderline between the familiar and the outside world, emergence of talking animals and strange creatures. Projecting interior landscape outward onto nature, she weaves signs of indeterminacies into a healing scene for lonely men or lost young adults. The melancholy and ephemerality may permeate her tales but in the end a ray of sunshine and a glimmer of hope is enclosed. Normality is restored, but coexisting with the strange. Keisuke Nishimoto, a contemporary Japanese children's writer, asserts that:

\section{"Naoko Awa's refreshing fantasy is, by its very nature, different from those sentimental fairy tales during the Meijiperiod, or the escapist folk tales. Far from merely longing, her fantastic world explores fundamental philosophical questions about what is human through her acute observation" (Peng, 2005:66).}

It is true that her stories not merely envision an eco-humanist picture of how various creatures interact with lost human beings, but also address the modern social issues brought by the alienation from the nature and animals. The stories endorse idiosyncrasies of Japanese cultural community by paying respect to the belief of all is related and relative. In general, Awa's "cross-border narrative", as pointed out in a book review, "mirrors the Japanese attitude toward nature, because man, animals, and nature are portrayed as interdependent elements, linked by bonds of mutual affection" (Cardi, 2011:177). Her works do justice to our expectation of a possible numinous venture into the otherness and the borderland against an oriental backdrop.

\section{Conclusion}

Naoko Awa's stories adapt many ingredients known from the literary tradition about the strange into her own creative experience. Her protagonists are usually put into a fantastic world after encountering outlandish animals, in which they are compelled to recover their sense of becoming an animal, a tree or even a grotesque yaoguai. At that point, vulnerable to the larger society that is full of binary oppositions or hybrid possibilities, they gradually reconcile themselves with these creatures. They need to figure out how to negotiate with strange creatures they encounter to achieve their mental equipoise in a disturbed 
world. As Rosemary Jackson points out, "Fantasy characteristically attempts to compensate for a lack resulting from cultural constraints: it is a literature of desire, which seeks that which is experienced as absence and loss" (1981:3). Journeying into Naoko Awa's shared forest, the agitated and solitary souls can eventually find their yearnings for the extraordinary and the connectedness reverberate. Magic realist encounters emerge as an ideal way to help release and reinterpret hidden voices in them, and then turnover to the readers.

\section{Bibliography}

Awa, Naoko, and Toshiya Kamei. 2009. The Fox's Window: And Other Stories. New Orleans: U of New Orleans.

Awa, Naoko. 2012. Guests of Red Rose Inn. Beijing: Jieli.

Awa, Naoko. 2011. Forest of White Parrots. Shanghai: Juvenile \& Children's Publishing House.

Awa, Naoko. "Yaojing in My Works." ErtongWenyi Sept. 1977. Web. 27 Feb. 2015. <http:// www.kanunu8.com/book/4444/56312. html>.

Bai, Ze. "On Energy." Edge of Perspective.MediaWiki, 6 Apr. 2013. Web. 5 Mar. 2015. $<$ http://wiki.edgeofperspective.net/index. php?title=Excerpts_from_the_Bai_Ze\%27s_ Archive:_On_Energy>.

Balmain, Colette. 2008. Introduction to Japanese Horror Film. Edinburgh: Edinburgh UP.

Bryce, Mio. 2012. "All is Relative, Nothing is Reliable: Inuyasha and Japanese Subjectivities". Stephens, John (ed.) Subjectivity in Asian Children's Literature and Film: Global Theories and Implications. New York: Routledge.

Cardi, Luciana. 2015. "Review: The Fox's Window and Other Stories." Marvels \& Tales 25.1 (2011): 176-78. JSTOR. Web. 27 Feb.
Chiang, Sing-chen Lydia. 2005. Collecting the Self: Body and Identity in Strange Tale Collections of Late Imperial China. Boston: Brill.

Cosslett, Tess. 2002. "Child's Place in Nature: Talking Animals in Victorian Children's Fiction." Nineteenth-Century Contexts 23.4: 475-95.

Dodd, Sarah. 2011. "Changing Skin: The Monstrous in Liaozhaizhiyi", in Seth Alcorn and Steven A. Nardi (ed,) Twisted Mirrors: Monstrous Reflections of Humanity. UK: Interdisciplinary Press.

Foucault, Michel. 1971. The Order of Things: An Archaeology of the Human Sciences. New York: Pantheon.

Jackson, Rosemary. 1981. Fantasy, the Literature of Subversion. London: Methuen

Mendlesohn, Farah. 2008. Rhetorics of Fantasy. Middletown: Wesleyan UP.

Mo, Yan, and Howard Goldblatt. 2008. Life and Death Are Wearing Me Out: A Novel. New York: Arcade Pub.

Peng, Yi. 2005. "Naoko Awa and Her Enchanting Forest." Editors Bimonthly 1: 64-67. . 2014. Yaoguai Mountain. Beijing: SinoComic.

Sax, Boria. 2013. Imaginary Animals: The Monstrous, the Wondrous and the Human. London: Reaktion.

Sharpiro, Jerome F. 2002. Atomic Bomb Cinema. New York: Routledge.

Sieber, Sharon. 2012. "Magical Realism" in The Cambridge Companion to Fantasy Literature. Cambridge: Cambridge UP.

Todorov, Tzvetan. 1973. The Fantastic: A Structural Approach to a Literary Genre. Ithaca: Cornell UP.

Zeitlin, Judith T. 1993. Historian of the Strange: PuSongling and the Chinese Classical Tale. Stanford: Stanford UP. 